\title{
Penerapan Model Pembelajaran Cooperative Tipe TAI (Team Assisted Individualization) untuk Meningkatkan Hasil Belajar dan Kemampuan Berpikir Kritis Matematika
}

\author{
Rizky Ratna Wijayanti ${ }^{*}$, Stefanus Christian Relmasira² ${ }^{2}$ Janelle Lee Juneau ${ }^{3}$ \\ 1,2,3 Jurusan Pendidikan Guru Sekolah Dasar (PGSD), FKIP Universitas Kristen Satya Wacana, Indonesia.
}

\author{
A R T I C L E I N F O \\ Article history: \\ Received 20 August 2018 \\ Received in revised form \\ 12 September 2018 \\ Accepted 18 October 2018 \\ Available online 29 \\ November 2018

\begin{tabular}{l}
\hline Kata Kunci: \\
team assisted \\
individualization, hasil \\
belajar, kemampuan \\
berpikir kritis \\
Keywords: \\
team assisted \\
individualization, learning \\
out comes, critical thinking
\end{tabular}

\begin{abstract}
A B S T R A K
Penelitian tindakan kelas yang dilakukan dengan menggunakan model pembelajaran team assisted individualization untuk meningkatkan hasil belajar dan kemampuan berpikir kritis siswa kelas 3 SD Negeri Sumogawe 01 Getasan. Analisis data menunjukan hasil belajar siswa dalam kategori tidak tuntas mengalami penurunan. Dalam pra siklus ketidak tuntasan yang dicapai sebesar $57,5 \%$, pada siklus 1 mengalami penurunan menjadi $32,5 \%$ dan pada siklus kedua mengalami penurunan hingga mencapau angka 7,5\%. Sedangkan untuk kemapuan berpikir kritis siswa juga mengalami peningkatan yang cukup baik, pada pra siklus dapat disimpulkan bahwa kemampuan berpikir kritis siswa rata-rata hanya $62 \%$ dalam kategori rendah, pada siklus I meningkat menjadi $68 \%$ pada kategori sedang, dan pada pada siklus 2 mengalami peningkatan sebesar $68 \%$ dalam kategori sedang.
\end{abstract}

\section{A B S T R A C T}

Classroom action research was carried out using cooperative learning type team assisted individualization to improve learning outcomes and critical thinking skills of grade 3 students at $S D$ Negeri Sumogawe 01 Getasan. Data analysis shows that student learning outcomes in the incomplete category have decreased. In the pre-cycle of incompleteness achieved at 57.5\%, in the first cycle decreased to $32.5 \%$ and in the second cycle decreased to reach $7.5 \%$. While for the ability of critical thinking students also experienced a fairly good increase, in the pre-cycle it can be concluded that students' critical thinking skills on average only $62 \%$ in the low category, in the first cycle increased to $68 \%$ in the medium category, and in the second cycle experienced $68 \%$ increase in the medium category. 


\section{Pendahuluan}

Belajar bukanlah hal yang asing bagi manusia. Belajar merupakan sebuah kebutuhan pokok yang wajib dilakukan oleh manusia. Dengan belajar manusia mampu memahami dan mengerti tentang segala sesuatu yang ada dilingkungannya maupun dirinya sendiri. Menurut Anwar \& Harmi (2011) belajar adalah, "Aktivitas mental atau psikis yang berlangsung dalam interaksi aktif dengan ligkungan yang menghasilkan perubahan, pemahaman, keterampilan dan nilai sikap." "Hasil belajar merupakan perubahan perilaku yang diperoleh siswa setelah melakukan proses pembelajaran. Perubahan perilaku tersebut tergantung pada apa yang dipelajari siswa dan bagaimana proses pembelajaran berlangsung" (Hamdani, 2011).

Stefanus \& Mesti (2018) mengatakan bahwa matematika merupakan ilmu tentang bilangan dan berhubungan erat dengan hitung menghitung melalui cara berfikir untuk menganalisa suatu pernyataan dengan menggunakan logika. Ramlan (2013) mengatakan bahwa, "Matematika yang dipilih adalah matematika yang dapat menata nalar, membentuk kepribadian, menanamkan nilai-nilai, memecahkan masalah, dan melakukan tugas tertentu."

Matematika adalah ilmu tentang bilangan-bilangan dan prosedur operasional yang digunakan dalam penyelesaian masalah mengenai bilangan (Fatmawati, 2014). Matematika adalah salah satu mata pelajaran yang diujikan dalam ujian nasional tingkat sekolah dasar. Undang-undang RI Nomor 20 tahun 2003 tentang Sistem Pendidikan Nasional menegaskan bahwa pembelajaran matematika dimaksudkan untuk mengembangkan logika dan kemampuan berpikir peserta didik. Matematika di sekolah dasar mengkaji tentang mengenal, memahami, berhitung, dan mahir terampil menggunakan bilangan yang kaitannya dengan kehidupan sehari-hari. Tujuan pembelajaran matematika dalam Kurikulum 2006 (KTSP) (Rihadatulaisy, 2016) adalah agar peserta didik memiliki kemampuan memecahkan masalah yang meliputi kemampuan memahami masalah, merancang model matematika, menyelesaikan model, dan menafsirkan solusi yang diperbolehkan. Sehingga dengan demikian matematika dapat melatih cara berpikir siswa secara sistematis, logis, kritis, kreatif, dan konsisten.

"Dalam proses berpikir terdapat juga didalamnya kegiatan meragukan, memastikan, merancang, menghitung, mengukur, mengevaluasi, membandingkan, mengelompokkan, menggolongkaln, memilahmilah, membedakan, menafsir, melihat kemungkinan yang ada, menganalisis dan sintesis, menalar dan menarik kesimpulan, menimbang, dan memutuskan" (Maulana, 2017). Dalam berpikir kritis siswa mampu mengenali permaslahan yang dihadapi dan tau bagaimana harus menyelesaikannya.

Berdasarkan observasi dan wawancara dengan guru kelas SDN Sumogawe 01 yang dilakukan peniliti, ditemukan beberapa hal diantaranya: 1). Sumber belajar yang kurang memadai, keterbatasan alat peraga dan media pembelajaran embuat proses belajar menjadi monoton dan tidak efisien. 2). Kegiatan pembelajaran yang terlihat satu arah dan berpusat pada guru, 2). Fokus siswa terhadap pembelajaran masih kurang dan mudah teralihkan 3). Siswa masih kesulitan dalam menganalisis dan memecahkan permasalahan yang timbul dalam soal, sehingga kemampuan berpikir kritisnya tidak nampak, 4). Hasil belajar siswa pada tes semester 2 menunjukan bahwa hanya $42,5 \%$ siswa yang dinyatakan memiliki nilai diatas KKM (70). Sehingga dari sini nampak bahwa kemampuan berpikir kritis siswa dalam pembelajaran matematika masih kurang.

Supriyadi (2005) "Proses berpikir dapat ditinjau dari dua sisi yang berbeda yaitu filsafat dan psikologi. Bidang filsafat memberikan penekanan lebih besar terhadap studi tentang kemampuan berpikir kritis (critical thinking). Bidang psikologi lebih berpusat pada kajian tentang mekanisme berpikir (mechanism of mind)." Menurut Ennis ada 12 indikator berpikir kritis yang dikelompokkan dalam 5 aspek berpikir kritis(Maulana, 2017). 5 aspek berpikir kritis yang dikemukakan oleh Ennis adalah sebagai berikut; 1) Elementary Clarification, 2) Basic Support, 3) Inference, 4) Advance Clarification, 5) Strategy and Tactics. 12 Indikator yang ada dalam kemampuan berpikir kritis adalah; 1) Memfokuskan pertanyaan, 2) Menganalisis argumen, 3) Bertanya dan menjawab pertanyaan tentang suatu penjelasan atau tantangan. 4) Mempertimbangkan kredibilitas suatu sumber. 5) Mengobservasi dan mempertimbangkan hasil observasi. 6) Membuat deduksi dan mempertimbangkan hasil deduksi. 7) Membuat induksi dan mempertimbangkan hasil induksi. 8) Membuat keputusan dan mempertimbangkan hasilnya, 9) Mendefinisikan istilah dan mempertimbangkan definisi. 10) Mengidentifikasi asumsi. 11) Memutuskan suatu tindakan. 12) Berinteraksi dengan orang lain.

Untuk mengatasi masalah yang dialami siswa kelas 3 SD Negeri Sumogawe 01 adalah dengan melakukan tindakan dengan model pembelajaran cooperative tipe TAI (Team Assisted Individualization). Tarim \& Akdeniz (2007), "TAI method of cooperative learning takes into account both team achievement and individual work, it can be stated that it leads to better outcomes in mathematics classes." Slavin dan Kweit mengemukakan bahwa, "The team assisted individualized (TAI) instruction has been found effective in facilitating mathematics performance." Shalomo Sharan (2012) juga mengatakan bahwa, 
"Program matematika yang paling baik adalah yang menggabungkan pembelajaran kooperatif dengan pengajaran individual."

Adapun komponen pembelajran kooperatif tipe TAI adalah sebagai berikut (Georgina M. Tinungki 2015). a) Placement Test, Guru memberikan pretest kepada siswa. Metode ini digunkan untuk menempatkan siswa berdasarkan hasil belajar sebelumnya. Hal ini mempermudah guru untuk mengetahui kemampuan siswa dalam berbagai topik pembelajaran. b) Teams, siswa dibagi menjadi beberapa kelompok dengan anggota 4-5 orang. Satu kelompok terdiri dari laki-laki dan perempuan dengan kemampuan yang berbeda dari yang tinggi, sedang, dan rendah. c) Teaching Group, Guru menjelaskan materi yang akan dipelajari terlebih dulu sebelum memberikan tugas. d) Student Creative, Guru menekankan kepada siswa bahwa keberhasiln indivdu sangatlah penting didalam keberhasilan kelompok. e) Team Study, siswa belajar menggunakan LKS. Guru memberikan bimbingan untuk siswa yang membutuhkan bantuan secaara individual. Bukan hanya guru namun juga siswa yang memiliki kemampuan yang baik dapat membantu siswa yang lain didalam kelompok. f) Fact test, guru memberikan kuis berdasarkan fakta yang diterima siswa. g) Team Score dan Team Recognition,guru memberi penghargaan pada kelompok berdasarkan perolehan nilai peningkatan hasil belajar individual dari skordasar ke skor kuis berikutnya. h) Whole-Class Units, guru menjelaskan kembali tentang materi yang dipelajari dengan menggunakan strategi pemecahan masalah untuk semua siswa dikelas.

Melalui penerapan model pembelajaran TAI diharapkan dapat meningkatkan hasil belajar dan kemampuan berpikir kritis siswa dalam memecahkan masalah matematika.

\section{Metode}

Penelitian ini berjenis Penelitian Tindakan Kelas (PTK). Penelitian ini menggunakan design penelitian model spiral Kemmis dan Mc Taggart. "Penelitian ini dilakukan dalam dua siklus, dimana setiap siklusnya terdiri dari empat kegiatan yang dilakukan berulang yaitu perencanaan (planning), tindakan (acting), pengamatan (observing), refleksi (reflecting")(Arikunto, Suharsimi, 2017).

Subjek penelitian ini adalah siswa kelas 3 SD Negeri Sumogawe 01 yang berjumlah 40 orang siswa, jumlah laki-laki 21 orang siswa dan jumlah siswa perempuan 19 siswa. Penelitian ini dilakikan selama bulan Juni sampai Agustus tahun 2018 di SD Negeri Sumogawe 01 Getasan. Penelitian ini dilakukan dengan teknik pengumpulan data yang digunakan adalah tes dan non tes. Teknik ini digunakan untuk mengetahui hasil belajar siswa setelah dilakukan tindakan dengan model pembelajaran kooperatif tipe TAI. Tehnik pengumpul data yang digunakan adalah tehnik tes untuk mengetahui hasil belajar dan kemampuan berpikir siswa sebagai data kuantitatif. Sedangkan teknik pengumpul data non tes digunakan untuk menganalisis data kualitatif berupa hasil observasi guru dan siswa.

Data yang akan diperoleh dalam penelitian ini berupa: 1). data hasil observasi kegiatan guru, 2). data hasil observasi kegiatan siswa, 3). data hasil tes evaluasi siswa dalam siklus I dan siklus II. Indikator keberhasilan penelitian ini adalah ketuntasan siswa yang mencapai $70 \%$ dari jumlah seluruh siswa.

\section{Hasil dan Pembahasan}

Berdasarkan observasi dan wawancara dengan guru kelas SDN Sumogawe 01 yang dilakukan peniliti, ditemukan beberapa hal diantaranya: 1). Sumber belajar yang kurang memadai, keterbatasan alat peraga dan media pembelajaran embuat proses belajar menjadi monoton dan tidak efisien. 2). Kegiatan pembelajaran yang terlihat satu arah dan berpusat pada guru, 2). Fokus siswa terhadap pembelajaran masih kurang dan mudah teralihkan 3). Siswa masih kesulitan dalam menganalisis dan memecahkan permasalahan yang timbul dalam soal, sehingga kemampuan berpikir kritisnya tidak nampak, 4). Hasil belajar siswa pada tes semester 2 menunjukan bahwa hanya $42,5 \%$ siswa yang dinyatakan memiliki nilai diatas KKM (70). Sehingga dari sini nampak bahwa kemampuan berpikir kritis siswa dalam pembelajaran matematika masih kurang. Untuk meningkatkan hasil belajar dan kemampuan berpikir kritis peneliti menggunakan model pembelajaran kooperatif tipe TAI dalam pembelajaran matematika.

Peneliti membuat skenario pembelajaran dan media pembelajaran. Peneliti juga menyiapkan instrumenpenelitian berupaa rencana pelaksanaan pembelajaran (RPP), soal setiap pertemuan pada siklus 1, menyiapkan soal post test siklus 1 , menyiapkan instrumen observasi kegiatan guru dan siswa di siklus 1, dan menyiapkan papan skor dan bintang, serta hadiah untuk siswa. Peneliti menyediakan media pembelajaran berupa gambar es krim dan cones yang digunakan dalam pertemuan 1 untuk menjelaskan konsep perkalian dan cara menentukan jawaban dengan menggunakan penjumlahan berulang. Pada ppertemuan 2 media yang digunakan adalah gambar permen dan bunga yang digunakan untuk menjelaskan tentang konsep pembagian dan menentukan jawaban menggunakan pengurangan beruntun. 
Pertemuan ketiga hanya mereview tentang materi pertemuan 1 dan 2 sekaligus menjadi bahan untuk melakukan post test siklus 1 .

Dalam pelaksanaan peneliti menggunakan 2 jam pelajaran untuk melakukan satu kali pertemuan. Materi yang dipelajari adalah menegenai konsep perkalian. Cara mengerjakan soal perkalian berbentuk soal cerita dan cara menghitung perkalian dan pembagian dengan menggunakan penjumlahan beruntun dan pengurangan beruntun. Guru menggunakan gambar sebagai alat bantu menjelaskan mengenai konsep perkalian agar lebih menarik dan mudah dipahami. Siswa diminta untuk menegerjakan soal secara individu untuk mengukur pemahaman siswa mengenai konsep yang sedang diajarkan. Guru memberikan alat peraga berupa biji jagung dan cup untuk melakukan kuis perkalian. Guru membacakan kuis perkalian dan siswa menghitung dengan menggunakan biji jagung didalam kelompok. Guru memberikan soal mengenai perkalian untuk dikerjakan didalam kelompok. Siswa saling membantu dan mengkoreksi jawaban teman yang salah didalam kelompok. Guru turut serta membantu kelompok atau individu yang mengalami kesulitan. Guru memberikan sebuah kuis kecil (fact test) untuk siswa. Siswa atau kelompok yang memiliki skor paling banyak akan mendapatkan bintang sebagai hadiah di siklus 1 .

Setelah dilaksanakan tindakan siklus I maka hasil observasi yang dilakukan dalam proses pembelajaran siklus I terdapat beberapa kendala yang dihadapi, diantaranya; 1) classroom manajemen yang kurang, sehingga pembelajaran yang dilakukan kurang kondusif. 2) Dalam kegiatan belajar kelompok masih ada beberapa siswa yang tidak mau bergabung dengan temannya dan tidak mau berdiskusi. 3) Sebagian siswa masih belum mampu menguasai materi dengan baik. 4) masih ada siswa yang belum paham sama sekali akan materi yang dipelajari. 5)Masih adanya siswa yang suka mengganggu temannya dan membuat kegiatan pelajaran terhambat. 6) masih ada siswa yang hanya mensontek temannya dan tidak mau berusaha mengerjakan. 7) beberapa siswa masih ada yang lebih nyaman bertanya kepada guru daripada kepada teman. 8) Penggunaan waktu pembelajaran belum efektif, terbukti dalam kegiatan pembelajaran masih kekurangan waktu. Pada Siklus I, nilai hasil belajar dan kemampuan berpikir kritis siswa mengalami peningkatan. Hasil belajar yang diperoleh siswa pada pra siklus mendapat rata-rata 61,5 meningkat menjadi 72,25 . Sedangkan untuk kemampuan berpikir kritis siswa dalam siklus I meningkat dari $62 \%$ menjadi $68 \%$.

Solusi yang diambil guru untuk melakukan perbaikan disiklus II adalah; Guru akan menjelaskan kembali menegnai bagaimana konsep perkalian dan pembagian disetiap pertemuan. Guru akan membimbing siswa untuk berdiskusi dengan teman dan saling bertukar ide dan informasi. Guru akan membimbing siswa yang benar-benar belum mampu memahami materi secara intensif.

Setelah dilakukan perbaikan pada siklus II, terlihat bahwa pada siklus II berjalan sesuai dengan apa yang diharapkan. Terjaddi peningkatan hasil belajar, pda siklus I rata-rata yang diperoleh adalah 67,5\% dan terjadi peningkatan pada siklus II dengan rata-rata mencapai 92,5\%. Kemampuan berpikir kritis siswa juga mengalami peningkatan, pada siklus 1 rata-rata kemampuan berpikir kritis siswa $68 \%$ dengan kategori Sedang. Pada siklus II mengalami peningkatan sebesar $76 \%$ yang memiliki kategori sedang. Kegiatan Siklus II ini dapat dikatakan berhasil, karena terjadi peningkatan hasil belajar sebesar $25 \%$ dan untuk kemampuan berpikir kritis mengalami kenaikan sebesar 8\%.

Dengan demikian maka dapat dilihat perubahan peningkatan hasil belajar dan kemampuan berpikir kritis yang telah dikenai model pembelajara TAI.

Tabel 1. Perbandingan Hasil Belajar Pra Siklus, Siklus I, dan Siklus II

\begin{tabular}{|c|c|c|c|c|c|c|}
\hline \multirow{2}{*}{ Ketuntasan } & \multicolumn{2}{|c|}{ Pra Siklus } & \multicolumn{2}{|c|}{ Siklus I } & \multicolumn{2}{|c|}{ Siklus II } \\
\hline & $\mathrm{f}$ & $\%$ & $\mathrm{f}$ & $\%$ & $\mathrm{f}$ & $\%$ \\
\hline Tuntas & 17 & $42,5 \%$ & 27 & $67,5 \%$ & 37 & $92,5 \%$ \\
\hline Tidak Tuntas & 23 & $57,5 \%$ & 13 & $32,5 \%$ & 3 & $7,5 \%$ \\
\hline Rata-rata & \multicolumn{2}{|c|}{61,5} & \multicolumn{2}{|c|}{72,25} & \multicolumn{2}{|c|}{80,25} \\
\hline Nilai Maximum & \multicolumn{2}{|c|}{90} & \multicolumn{2}{|c|}{90} & \multicolumn{2}{|c|}{95} \\
\hline Nilai Minimum & \multicolumn{2}{|c|}{30} & \multicolumn{2}{|c|}{58} & \multicolumn{2}{|c|}{67} \\
\hline
\end{tabular}

Dari Tabel diatas dapat dilihat bahwa hasil belajar matematika yang dikenai tindakan model pembelajaran TAI (team Assisted Individualization mengalami peningkatan. Ntuk lebih jelasnya dapat dilihat dari diagram berikut; 


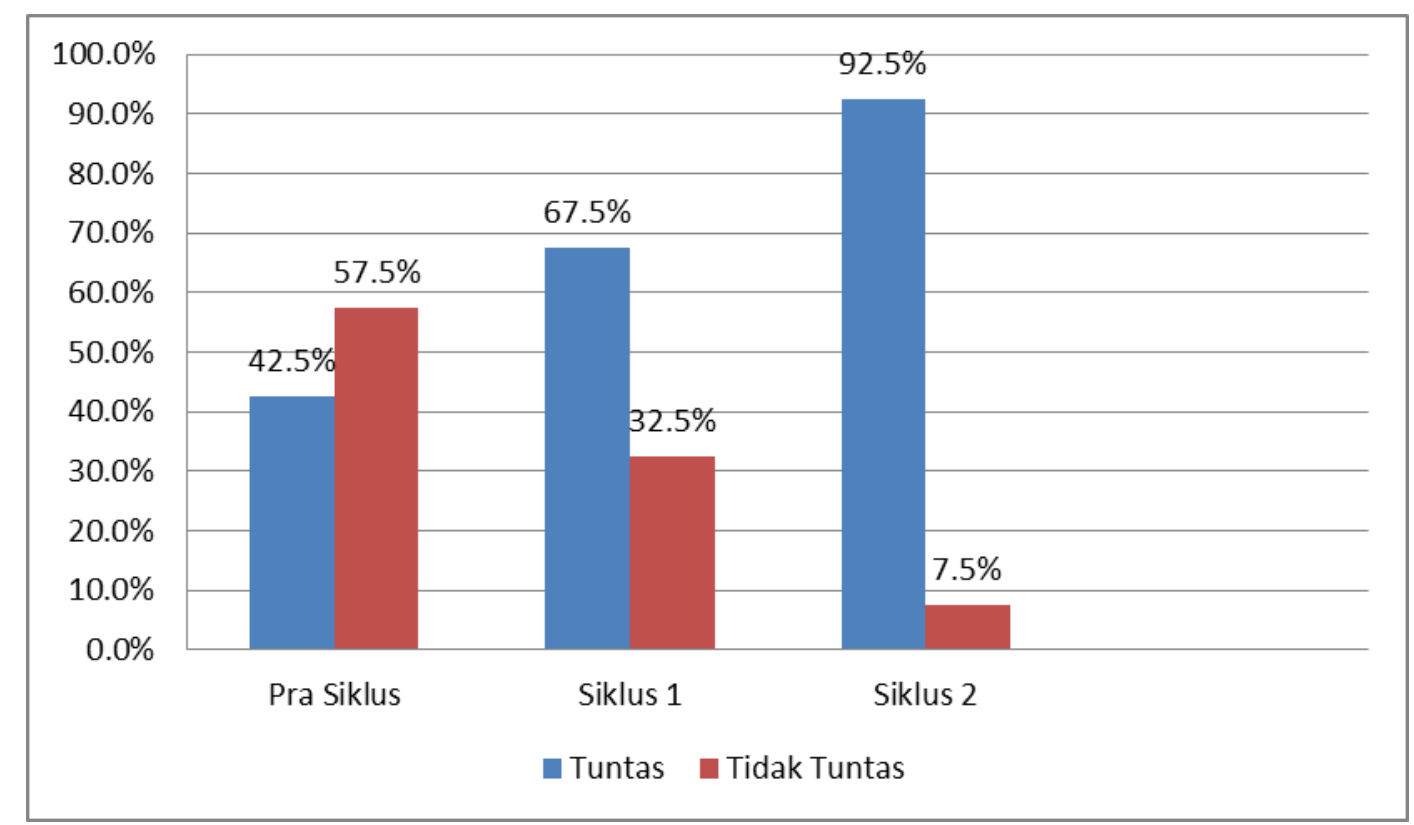

Diagram 1. Diagram Peningkatan Hasil Belajar Matematika Pra Siklus, Siklus I, Dan Siklus II

Pada pra siklus ketuntasan hasil belajar Matematika siswa adalah sebesar 42,5\% (17 siswa dari 40 siswa), sedangkan yang tidak tuntas sebesar 57,5\% (23 siswa dari 40 siswa) dengan nilai rata-rata 61,5. Pada siklus 1 ketuntasan sebesar 67,5\% (27 siswa dari 40 siswa), sedangkan yang tidak tuntas 32,5\% (13 siswa dari 40 siswa dengan rata-rata 72,25. Pada siklus II ketuntasan sebesar 92,5\% (37 siswa dari 40 siswa), sedangkan yang tidak tuntas 7,5\% ( 3 siswa dari 40 siswa dengan rata-rata 80,25.

Berikut adalah hasil peningkatan kemampuan berpikir kritis yang dikenai tindakan team assisted individualization;

Tabel 2. Peningkatan Kemampuan Berpikir Kritis Pra Siklus, Siklus I, dan Siklus II

\begin{tabular}{lccccccc}
\hline \multirow{2}{*}{ Ketuntasan } & Presentase skor & \multicolumn{2}{c}{ Pra Siklus } & \multicolumn{2}{c}{ Siklus I } & \multicolumn{2}{c}{ Siklus II } \\
& & $\mathrm{f}$ & $\%$ & $\mathrm{f}$ & $\%$ & $\mathrm{f}$ & $\%$ \\
\hline \multirow{2}{*}{ Sangat tinggi } & $89 \%<x \leq 100 \%$ & 0 & $0 \%$ & 1 & $2,5 \%$ & 0 & $0 \%$ \\
Tinggi & $79 \%<x \leq 89 \%$ & 3 & $7,5 \%$ & 5 & $12,5 \%$ & 15 & $38 \%$ \\
Sedang & $64 \%<x \leq 79 \%$ & 13 & $32,5 \%$ & 18 & $45,0 \%$ & 25 & $63 \%$ \\
Rendah & $54 \%<x \leq 64 \%$ & 5 & $12,5 \%$ & 16 & $40,0 \%$ & 0 & $0 \%$ \\
Sangat rendah & $x \leq 54 \%$ & 9 & $22,5 \%$ & 6 & $15,0 \%$ & 0 & $0 \%$ \\
& Rata-rata & \multicolumn{2}{c}{$62 \%$} & & $68 \%$ & & $76 \%$ \\
\hline
\end{tabular}

Dari tabel diatas dapat dilihat bahwa kemampuan berpikir kritis matematika yang dikenai tindakan model pembelajaran TAI (team Assisted Individualization mengalami peningkatan. Ntuk lebih jelasnya dapat dilihat dari diagram berikut; 


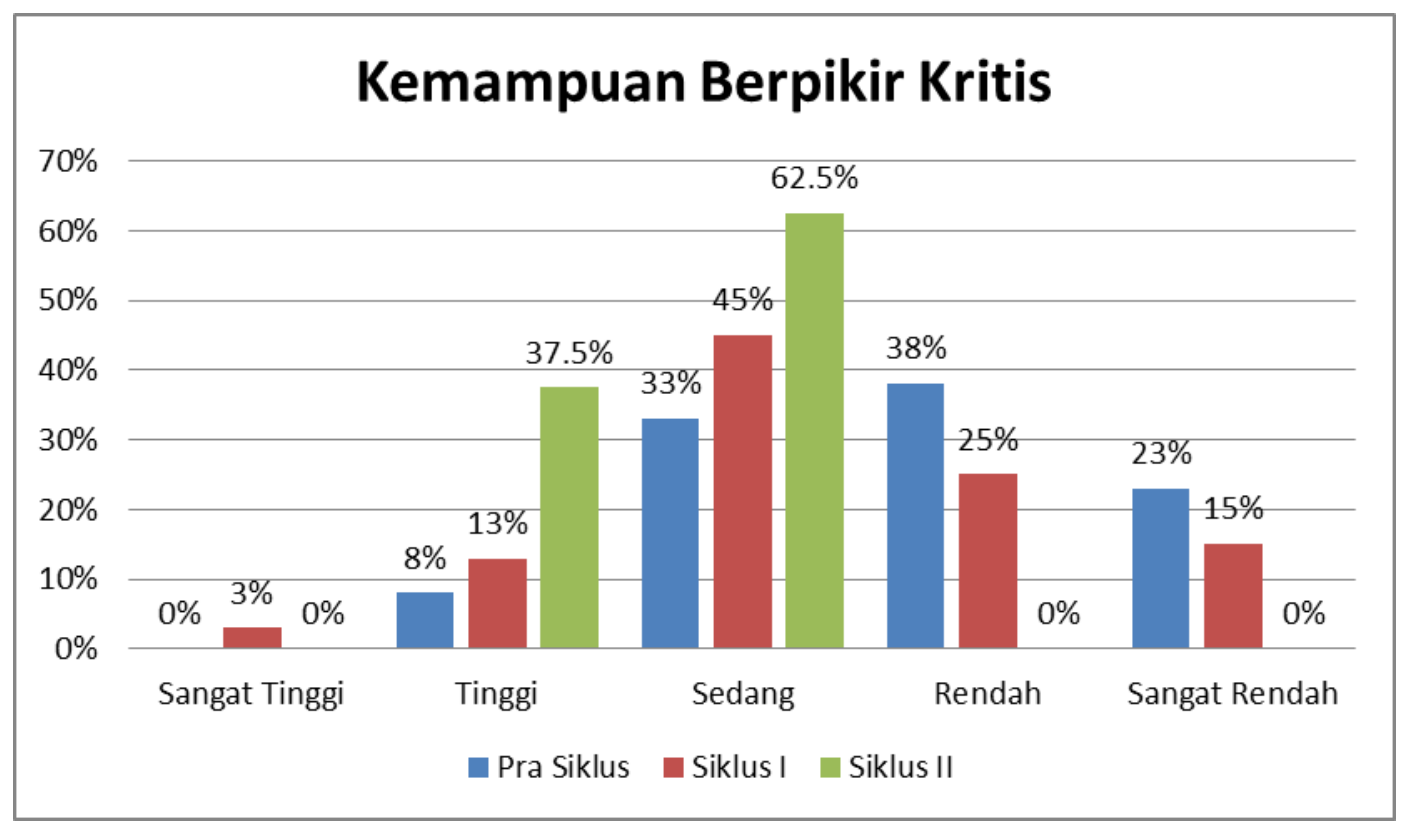

Diagram 1. Diagram Peningkatan Kemampuan Berpikir Kritis Matematika Pra Siklus, Siklus I, Dan Siklus

Diagram tersebut menjelaskan bahwa tingkat kemampuan berpikir kritis siswa dari pra siklus sampai siklus I mengalami peningkatan. Pada pra siklus kemampuan berpikir kritis 7,5\% siswa (3 siswa dari 40siswa) yang memiliki kemampuan berpikir kritis kategori tinggi, 32,5\% siswa (13 siswa dari 40 siswa) yang memiliki kemampuan berpikir kritis kategori sedang, 12,5\% siswa (5 siswa dari 40) yang memiliki kemampuan berpikir keritis kategori rendah, dan 22,5\% siswa ( 9 siswa dari 40 siswa) memiliki kemampuan berpikir kategori sangat rendah. Pada siklus I menjadi 2,5\% siswa (1 siswa dari 40 siswa) yang memiliki kemampuan berpikir kritis sangat tinggi, 12,5\% siswa (5 siswa dari 40 siswa) yang memiliki kemampuan berpikir kritis tinggi, 45\% siswa (18 siswa dari 40 siswa) yang tingat berpikirnya sedang, 40\% siswa (16 siswa dari 40 siswa) yang tingkat berpikirnya rendah, dan 15\% siswa (6 siswa dari 40 siswa) yang tingkat berpikirnya sangat rendah. pada siklus II tmenjadi 37,5\% siswa (15 siswa dari 40 siswa) yang memiliki kemampuan berpikir kritis tinggi dan 62,5\% siswa (25 siswa dari 40 siswa) yang tingat berpikirnya sedang.

Berdasarkan observasi dan refleksi tindakan yang telah dilakukan oleh guru, pelaksanaan tindakan pembelajaran pada pelajaran Matematika dengan menggunakan model pembelajaran team assisted individualization telah berjalan sesuai dengan yang diharapkan. Penggunaan model pembelajaran team assisted individualization juga terbukti dapat meningkatkan ketrampilan berpikir kritis siswa dan hasil belajar matematika siswa. Hal itu terbukti dengan meningkatntya ketuntasan hasil belajar siswa kelas 3 SD Negeri Sumogawe 01 pada mata pelajaran Matematika.

Hasil penelitian ini sejalan dengan penelitian yang dilakukan oleh Andi Wijaya, Endah Rita S. Dewi, Veryliana Purnamasari pada tahun 2018 dengan judul "Pembelajaran Model Team Assisted Individualization Terhadap Kemampuan Berpikir Kritis Dan Hasil Belajar Siswa Sekolah Dasar”. Hasil dari penelitian ini disimpulkan bahwa terdapat pengaruh model pemelajaranb TAI terhadap kemampuan berpikir kritis matematika kelas V SD Negeri Sawah Besar02 Semarang. Penelitian yang dilakukan oleh I Nengah Indra Pramana, I W. Suwatra Gede Sedanayasa pada tahun 2014 dengan judul "Pengaruh Model Pembelajaran Kooperatif Tipe TAI (Team Assisted Individualization) Dan Yang Konvensional Terhadap Hasil Belajar Matematika Kelas IV di SD Wongaya Gede Tahun Pelajaran 2012/2013.

\section{Simpulan dan Saran}

Berdasarkan penelitian yang sudah dilakukan dengan menggunakan model pembelajaran team assisted individualization untuk meningkatkan hasil belajar dan kemampuan berpikir kritis siswa kelas 3 SD Negeri Sumogawe 01 Getasan, maka dapat disimpulkan bahwa model pembelajran TAI dapat meningkatkan hasil belajar dan kemampuan berpikir kritis siswa. Dalam kegiatan pembelajaran matematika terlihat bahwa siswa tidak tertari dengan pembelajaran yang disajikan. Selain itu siswa juga belum paham bagaimana cara memecahkan masalah soal cerita dan cara mengidentifikasinya agar mendapatkan kunci jawaban dari hal yang dimaksud dalam soal. Setelah dilakukan tindakan pada siklus 1 
dengan pembelajaran yang menggunkan gambar dan alat peraga membuat siswa lebih antusias dan tertarik untuk belajar.

Analisis data menunjukan hasil belajar siswa dalam kategori tidak tuntas mengalami penurunan. Dalam pra siklus ketidak tuntasan yang dicapai sebesar 57,5\%, pada siklus 1 mengalami penurunan menjadi 32,5\% dan pada siklus kedua mengalami penurunan hingga mencapau angka 7,5\%. Sedangkan untuk kemapuan berpikir kritis siswa juga mengalami peningkatan yang cukup baik, pada pra siklus dapat disimpulkan bahwa kemampuan berpikir kritis siswa rata-rata hanya 62\% dalam kategori rendah, pada siklus I meningkat menjadi 68\% pada kategori sedang, dan pada pada siklus 2 mengalami peningkatan sebesar $68 \%$ dalam kategori sedang.

Penelitian tindakan kelas yang dilaksanakan sudah memenuhi keberhasilan yang sudah ditetpkan terjadi peningkatan $70 \%$ pada kemampuan berpikir kritis dan $70 \%$ pada hasil belajar. Pada indikator proses pelaksanaan model TAI juga sudah terlaksana 100\%. Sehingga pelaksanaan penelitian tindakan kelas ini dapat disimpulkan bahwa penerapan model team assisted individualization dapat meningkatkan kemampuan berpikir krirtis siswa dan hasil belajar.

\section{Daftar Rujukan}

Anwar, K., \& Harmi, H. (2011). Perencanaan Sistem Pembelajaran Kurikulu Tingkat Satuan Pendidikan (KTSP). Bandung: Alfabeta.

Arikunto, Suharsimi. (2017). Manajemen Peneitian. Jakarta: Rineka Cipta.

Fatmawati, H. (2014). Analisis Berpikir Kritis Siswa Dalam Pemecahan Masalah Matematika Berdasarkan Polya Pada Pokok Bahasan Persamaan Kuadrat (Penelitian pada Siswa Kelas X SMK Muhammadiyah 1 Sragen Tahun Pelajaran 2013/2014). Jurnal Elektronik Pembelajaran Matematika , 911.

Hamdani. (2011). Strategi Belajar Mengajar. Bandung : Pustaka Setia.

M, R. (2013). Meningkatkan Self-Efficacy Pada Pembelajaran Matematika Melalui Model Kooperatif Tipe Team Assisted Individualization (TAI) Pada Siswa Kelas Viiasmp Negeri 27 Makassar. Jurnal Matematika Dan Pembelajaran (Mapan) , 112.

Maulana. (2017). Kemampuan Dasar Matematika dan Pengembangan Kemampuan Berpikir Kritis-Kreatif. Sumedang: UPI Sumedang Press.

Nurzakiaty, Ida. 2015. Penerapan Model Pembelajaran Kooperatif Tipe Team Assisted Individualization (TAI) Dalam Pembelajaran Integral Di Kelas XII IPA-2 SMA Negeri 8 Banda Aceh. Jurnal Peluang, Volume 3, Nomor 2.

Puspitasari, Luki. 2015. Penerapan Model Kooperatif Tipe Team Assisted Individualization (TAI) DALAM Peningkatan Pembelajaran IPA Di Kelas V. Kalam Cendekia, Volume 4, Nomor 2.

Ramlan, M. 2013. Meningkatkan Self-Efficacy Pada Pembelajaran Matematika Melalui Model Kooperatif Tipe Team Assisted Individualization (TAI) Pada Siswa Kelas VIIA SMP Negeri 27 Makassar. Jurnal Matematika Dan Pembelajaran (MAPAN), VOL. 1 NO. 1.

Relmasira, S. C., \& Romadhoni, M. F. (2018). Perbedaan Pengaruh Penerapan Model Pembelajaran Course Review Horay dan Quantum Teaching Dilihat dari Hasil Belajar Matematika Siswa Kelas 3 SD. Scholaria : Jurnal Pendidikan dan Kebudayaan, Vol. 8 No. 1 , 95.

Rihadatulaisy, D. (2016, May 15). Tujuan Pembelajaran Matematika Dalam Kurikulum 2006 (BSNP). Retrieved Januari 2, 2018, from Ktz30: http://katazikurasana30.blogspot.co.id/2016/05/tujuanpembelajaran-matematika-dalam.html

Sharan, S. (2012). Cooperative Learning. Yogyakarta: Familia.

Suryadi, D. (2011). Pendidikan Matematika. didi-suryadi.staff.upi.edu , 16-18.

Tarim, K., \& Akdeniz, F. (2007). The effects of cooperative learning on Turkish elementary students' 
mathematics achievement and attitude towards mathematics using TAI and STAD methods. Edu Stud Math .

Tinungki, G. M. (2015). The Role of Cooperative Learning Type Team Assisted Individualization to Improve the Students' Mathematics Communication Ability in the Subject of Probability Theory. IISTE .

Ujiati, Cahyaningsih. 2018. Penerapan Model Pembelajaran Kooperatif Tipe TAI (Team Assisted Individualization) Untuk Meningkatkan Hasil Belajar Siswa Pada Mata Pelajaran Matematika. Jurnal Cakrawala Pendas Vol. 4 No.1 